\title{
Potential efficacy of Coenzyme Q10 against oxytetracycline-induced hepatorenal and reproductive toxicity in male rats
}

\author{
Samah S. Oda ${ }^{1 *}$, Reham S. Waheeb ${ }^{2}$, Zeynab Kh. El-Maddawy ${ }^{3}$ \\ 'Department of Pathology, Faculty of Veterinary Medicine, Alexandria University, Egypt. \\ ${ }^{2}$ Department of Theriogenology, Faculty of Veterinary Medicine, Alexandria University, Egypt. \\ ${ }^{3}$ Department of Pharmacology, Faculty of Veterinary Medicine, Alexandria University, Egypt.
}

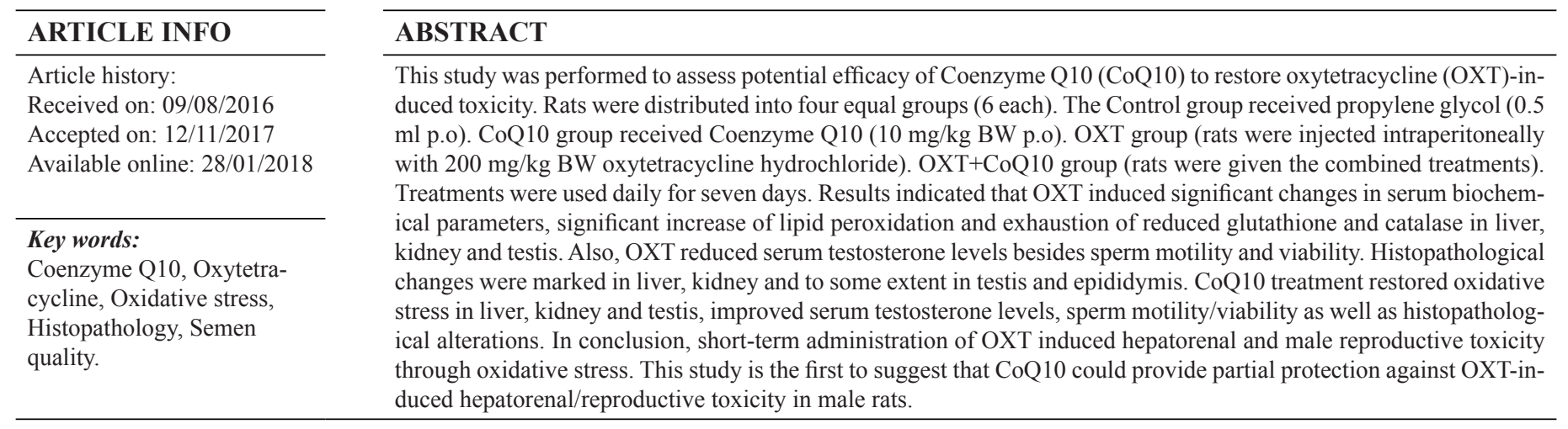

\section{INTRODUCTION}

Oxytetracycline (OXT) is a broad-spectrum antibiotic that is widely used in controlling respiratory diseases and other genital and skin infections in human and animals. Large doses of OXT without medical supervision have deleterious effects on kidney and liver (Abdel-Daim and Ghazy, 2015). While some studies reported no adverse effects of OXT on spermatogenesis (Abbitt et al., 1984), other studies have shown that repeated doses of OXT have toxic effect on mature sperm in-vivo (Oyedeji et al., 2013) and in-vitro (Hargreaves et al., 1998). OXT was shown to exert its toxic effect via peroxidation of membrane lipids, mitochondrial damage, and impairment of the respiratory chain (Fromenty and Pessayre, 1997). Also, reduced tissue antioxidants biomarkers are associated with OXT overdose (Gnanasoundari and Pari, 2006).

\footnotetext{
"Corresponding Author

Samah S. Oda, Assistant Professor of Pathology, Department of Pathology, Faculty of Veterinary Medicine, Alexandria University, Edfina-Rashid-Behera,Egypt.E-mail: samahoda@yahoo.com
}

Several studies investigated the effect of antioxidants to counteract OXT-induced oxidative stress and to alleviate its side effects in experimental animal models. For example, supplementation of ascorbic acid (Naseer and Alam, 1987), Naringenin "natural flavonoid" (Gnanasoundari and Pari, 2006), and Curcumin (Helal et al., 2011) showed protective action against OXT detrimental effects on liver and kidney.

Coenzyme Q10 (CoQ10) is a fat-soluble substance that is primarily present in mitochondria where it plays a role in electron transport chain and plays a part in aerobic cellular respiration and ATP production. Therefore, organs of high energy requirement such as liver, kidney, and heart have higher concentrations of CoQ10 (Aberg et al., 1992). Seminal plasma and spermatozoa also contain considerable amount of CoQ10 for protection against oxidative stress and preserving sperm integrity (Mancini and Balercia, 2011). Levels of CoQ10 in seminal plasma correlate significantly with sperm concentration and motility (Alleva et al., 1997).

To the best of the authors' knowledge, the protective efficacy of CoQ10 against OXT-induced toxicity has not been 
investigated previously. Therefore, the present study was planned to assess efficacy of supplementing CoQ10 on oxidative stress status, liver/kidney function, semen quality and histopathology in OXT-intoxicated rats.

\section{MATERIALS AND METHODS}

\section{Animals and experimental design}

Adult male albino rats (170-200 g) were obtained from a closed colony at Faculty of Agriculture, Alexandria University, Egypt. Rats were maintained in metal wire cages with free access to food and water. Twenty-four rats were allocated into four identical groups, six each. Control group, rats were administered $0.5 \mathrm{ml}$ of $20 \%$ propylene glycol using stomach tube. CoQ10 group, rats were administered Coenzyme Q10 that was dissolved in $20 \%$ propylene glycol $(10 \mathrm{mg} / \mathrm{kg} \mathrm{BW})$ using stomach tube (El-Sheikh et al., 2012). OXT group, rats were injected intraperitoneally with $200 \mathrm{mg} / \mathrm{kg}$ BW oxytetracycline hydrochloride solution (delta oxy ${ }^{\circledR} 5 \%$, Delta Pharma Company, Egypt) (Saraswat et al., 1997). OXT+CoQ10 group, rats were given the combined treatments with $1 \mathrm{hr}$ interval. Coenzyme Q10 was obtained from Mepaco-Medifood Company, Egypt. Treatments were used daily for seven days. This study was permitted by the committee of scientific research ethics, Faculty of Veterinary Medicine, Alexandria University.

\section{Body and relative organs weights}

Rats' body weight was recorded just prior start of the experiment with insignificant difference between all groups. On the $8^{\text {th }}$ day of the experiment, every rat was weighed, euthanized and dissected. Liver, kidneys, heart, testis, epididymis and accessory sex glands (prostate and seminal vesicle) were grossly examined and weighed. Index weight (IW) of each organ was calculated as follow: IW = organ weight $(\mathrm{g}) /$ body weight $(\mathrm{g}) \times 100$.

\section{Hematological, biochemical and testosterone level evalua- tion}

On the $8^{\text {th }}$ day of the experiment, two blood samples were drained just before euthanasia from every rat. One blood sample was collected in heparinized tubes for hematological analysis and the other one was collected in plain tubes for serum separation. Serum was kept frozen at $-20^{\circ} \mathrm{C}$ until used for biochemical and hormonal analysis. Hematological parameters were automatically measured by Mindray BC-30S Auto CBC Blood Hematology Analyzer Device. The evaluated hematological parameters were packed cell volume (PCV\%), red blood cells (RBCs), white blood cells (WBCs) counts and hemoglobin (HB) concentration. All biochemical parameters were tested colourimetrically using commercial kits (Biodiagnostic, Chemical Co., Egypt). Serum alanine aminotransferase (ALT) and aspartate aminotransferase (AST) activities were estimated according to Reitman and Frankel (1957) technique. Alkaline phosphatase (ALP) and gamma glutamyle transferase (GGT) were measured as the methods described by Kind and King (1954) and Szasz (1974), respectively. Serum total protein and albumin were estimated by using the method of Doumas et al. (1971). Serum globulin was calculated by subtracting the albumin value from total protein value of the same sample (Coles, 1974). Serum total bilirubin was analyzed according to Walter and Gerade (1970) method. Serum total cholesterol and triglycerides activities were estimated according to Johnson et al. (1999) and Fassati and Prencipe (1982), respectively. Also, serum urea was evaluated by enzymatic colourimetric technique of Coulomb and Farreau (1963). Serum creatinine was assessed colourimetrically according to Husdan and Rapoport (1968) technique. Testosterone was measured in serum by enzyme immunoassay kit (Immunometrics Ltd., London, UK) as described method of Demetrious (1987).

\section{Lipid peroxidation and antioxidant status}

Hepatic, renal and testicular specimens were collected and preserved frozen at $-20^{\circ} \mathrm{C}$ for assessment of lipid peroxidation (LPO), reduced glutathione (GSH) and catalase enzyme. LPO was evaluated as malondialdehyde (MDA) according to the technique of Ohkawa et al. (1979). MDA was estimated after thiobarbituric acid reaction in acidic medium at $95^{\circ} \mathrm{C}$ for 30 minutes forming thiobarbituric acid reactive product, the resultant pink product (absorbance was estimated spectrophotometrically at $534 \mathrm{~nm}$ ). GSH content was measured by the method of Sedlak and Lindsay (1968). The method is based on the reductive cleavage of 5,5-dithiobis-(2-nitrobenzoic acid) by sulfhydryl (-SH) group giving a yellow color with absorbance at $412 \mathrm{~nm}$. Catalase enzyme (CAT) activity was assayed according to Aebi (1974). Catalase activity was valued on the basis of the reaction of the enzyme with a recognized amount of $\mathrm{H} 2 \mathrm{O} 2$. The reaction is stopped after one minute with catalase inhibitor, in the existence of peroxidase (HRP) the remaining $\mathrm{H} 2 \mathrm{O} 2$ reacts with 3,5-Dichloro-2-hydroxybenzene sulforic acid (DHBS) and 4-aminophenazone (AAP) to form a chromophore with a color intensity (measured spectrophotometrically at $500-520 \mathrm{~nm}$ ) inversely proportional to the amount of the catalase in the original sample.

\section{Semen collection and evaluation of sperm motility}

After euthanasia of animals, epididymis of each rat was harvested and semen was squeezed from the cauda epididymis through an incision onto a pre-warmed microscope slide. Immediately, undiluted semen drop was assessed for mass motility using $0-5+$ scale under bright field microscope, magnification X100. Total and progressive motility were determined in diluted semen drop using $2.9 \%$ of pre-warmed sodium citrate then examined under the microscope (X400) equipped with warm stage; motility was estimated on a continuous scale of 0 to $100 \%$ (Mondal et al., 2013).

\section{Sperm concentration}

The concentration of spermatozoa (million/ml) was estimated by hemocytometer method using bright field optics (X400) (Sorensen, 1979).

\section{Live sperm percentage}

Alive spermatozoa percentage was evaluated using eosin-nigrosine stain in uniform smears using bright field optics (X400). At least 200 sperms were counted in 5 microscopic fields (Laing, 1979). 


\section{Pathological examination}

After euthanasia and dissection of rats, all organs were examined grossly. Specimens of liver, kidney, testis and epididymis were harvested and rapidly fixed in formalin solution $10 \%$ for at least 24 hours for histopathology. Fixed specimens were dehydrated in ascending alcohol solutions then cleared in xylene, embedded in paraffin blocks and sectioned by a microtome. Five $\mu \mathrm{m}$ thick sections were stained using hematoxylin and eosin (HE). Histopathological lesions were recorded and scored $(0=$ absent, $1=$ mild, $2=$ moderate and $3=$ severe).

\section{Statistical analysis}

Variances in body weight were assessed using a repeated measures analysis of variance (ANOVA). For variables measured once, we used one-way ANOVA with Duncan's Multiple Range post-hoc ranking of means. Arcsine and logarithmic transformations were performed on percentage data and sperm concentration, respectively before analysis to normalize their distribution. Ordinal scores of sperm mass motility and histopathologic lesions as well as non-normal and/or non-homogenous data were analyzed non-parametrically with Kruskal-Wallis test followed by Dunn's test for multiple comparisons. Data are expressed as mean \pm standard error of mean. $P>0.05$ was considered non-significant. SAS software (v9.1, SAS Institute Inc., Cary, NC, USA) was used to run all analyses.

\section{RESULTS}

\section{Body and relative organs weights}

Table 1 displays that final body weight of OXT and OXT+CoQ10 groups significantly $(P<0.05)$ decreased in comparison to control group. Liver and kidneys relative weights significantly increased in OXT and OXT + CoQ10 groups compared to control group. Testis relative weight significantly increased in OXT group. Combined treatment of OXT and CoQ10 showed no significant difference in testis relative weight. No significant difference was recorded in heart, epididymis and accessory sex glands relative weights in all treated groups compared to control group.

Table 1: Effect of oxytetracycline (OXT) and Coenzyme Q10 (CoQ10) on body weight (BW) and index organ weight (IW) of rats.

\begin{tabular}{lcccc}
\hline & Control & CoQ10 & OXT & $\begin{array}{c}\text { OXT+ } \\
\text { CoQ10 }\end{array}$ \\
\hline Initial BW (g) & $248 \pm 10.1^{\mathrm{a}}$ & $244 \pm 11.4^{\mathrm{a}}$ & $243 \pm 7.5^{\mathrm{a}}$ & $247 \pm 8.2^{\mathrm{a}}$ \\
Final BW (g) & $297 \pm 8.0^{\mathrm{a}}$ & $275 \pm 17.2^{\mathrm{a}}$ & $191 \pm 15.6^{\mathrm{b}}$ & $223 \pm 22.3^{\mathrm{b}}$ \\
Liver IW & $3.87 \pm 0.13^{\mathrm{b}}$ & $3.96 \pm 0.11^{\mathrm{ab}}$ & $5.26 \pm 0.34^{\mathrm{a}}$ & $4.90 \pm 0.20^{\mathrm{a}}$ \\
Kidney IW & $0.68 \pm 0.01^{\mathrm{b}}$ & $0.72 \pm 0.02^{\mathrm{ab}}$ & $1.70 \pm 0.47^{\mathrm{a}}$ & $1.52 \pm 0.24^{\mathrm{a}}$ \\
Heart IW & $0.38 \pm 0.03^{\mathrm{a}}$ & $0.41 \pm 0.03^{\mathrm{a}}$ & $0.47 \pm 0.01^{\mathrm{a}}$ & $0.46 \pm 0.01^{\mathrm{a}}$ \\
Testis IW & $1.10 \pm 0.06^{\mathrm{b}}$ & $1.17 \pm 0.05^{\mathrm{b}}$ & $1.51 \pm 0.17^{\mathrm{a}}$ & $1.36 \pm 0.11^{\mathrm{ab}}$ \\
Epididymis IW & $0.46 \pm 0.02^{\mathrm{a}}$ & $0.50 \pm 0.03^{\mathrm{a}}$ & $0.91 \pm 0.29^{\mathrm{a}}$ & $0.51 \pm 0.05^{\mathrm{a}}$ \\
Accessory glands IW & $0.72 \pm 0.05^{\mathrm{a}}$ & $0.77 \pm 0.06^{\mathrm{a}}$ & $0.52 \pm 0.11^{\mathrm{a}}$ & $0.54 \pm 0.11^{\mathrm{a}}$ \\
\hline
\end{tabular}

Values are means \pm standard errors. Means in the same row not sharing a common superscript letter are significantly different $(P<0.05)$. Index Weight $(\mathrm{IW})=$ organ weight $(\mathrm{g})$ /body weight $(\mathrm{g}) \times 100$.

\section{Hematological and serum biochemical results}

In comparison to control group, Table 2 illustrates that $\mathrm{HB}$ concentration, RBCs and WBCs counts were significantly $(P<0.05)$ declined in OXT and OXT+CoQ10 groups. PCV\% showed no significant alteration in OXT and OXT $+\mathrm{CoQ} 10$ groups. Also, there was a significant $(P<0.05)$ increase in serum activities of GGT, ALP, AST and total bilirubin, and a significant reduction in serum total proteins and albumin concentration in OXT and OXT+CoQ10 groups. CoQ10 treatment ameliorated serum AST levels in OXT+CoQ10 group compared to levels recorded in OXT group. No significant differences were recorded in serum ALT and serum cholesterol levels in all treated groups. Serum triglycerides levels were significantly reduced in CoQ10 treated groups, while it did not differ significantly in OXT group. Serum urea and creatinine values were significantly elevated in OXT and OXT + CoQ10 groups compared to control.

Table 2: Effect of oxytetracycline (OXT) and Coenzyme Q10 (CoQ10) on hematological and serum biochemical parameters of rats.

\begin{tabular}{|c|c|c|c|c|}
\hline & Control & CoQ10 & OXT & $\begin{array}{c}\text { OXT+ } \\
\text { CoQ10 }\end{array}$ \\
\hline PCV, \% & $37.9 \pm 0.44^{\mathrm{ab}}$ & $39.8 \pm 0.75^{\mathrm{a}}$ & $35.8 \pm 1.54^{\mathrm{b}}$ & $35.0 \pm 1.54^{b}$ \\
\hline $\mathrm{HB}, \mathrm{g} / \mathrm{dl}$ & $13.1 \pm 0.18^{\mathrm{a}}$ & $14.3 \pm 0.12^{\mathrm{a}}$ & $11.45 \pm 0.34^{\mathrm{b}}$ & $11.9 \pm 0.28^{\mathrm{b}}$ \\
\hline RBCs, $10^{6} / \mu \mathrm{l}$ & $6.4 \pm 0.09^{\mathrm{a}}$ & $6.77 \pm 0.20^{\mathrm{a}}$ & $5.73 \pm 0.14^{\mathrm{b}}$ & $5.84 \pm 0.10^{b}$ \\
\hline WBCs, $10^{3} / \mu 1$ & $13.4 \pm 0.51^{\mathrm{a}}$ & $13.7 \pm 0.45^{\mathrm{a}}$ & $10.5 \pm 0.79^{\mathrm{b}}$ & $11.1 \pm 0.80^{\mathrm{b}}$ \\
\hline GGT, U/L & $0.56 \pm 0.08^{\mathrm{b}}$ & $0.56 \pm 0.10^{\mathrm{b}}$ & $1.86 \pm 0.25^{\mathrm{a}}$ & $1.77 \pm 0.31^{\mathrm{a}}$ \\
\hline $\mathrm{ALP}, \mathrm{U} / \mathrm{L}$ & $201 \pm 17.76^{\mathrm{b}}$ & $197 \pm 14.51^{\mathrm{b}}$ & $425 \pm 37.6^{\mathrm{a}}$ & $410 \pm 39.9^{\mathrm{a}}$ \\
\hline $\mathrm{ALT}, \mathrm{U} / \mathrm{L}$ & $41.3 \pm 1.04^{\mathrm{a}}$ & $40.70 \pm 1.90^{\mathrm{a}}$ & $38.9 \pm 1.47^{\mathrm{a}}$ & $39.7 \pm 1.93^{\mathrm{a}}$ \\
\hline AST, U/L & $121 \pm 1.85^{\mathrm{c}}$ & $121 \pm 3.31^{\mathrm{c}}$ & $228 \pm 9.68^{\mathrm{a}}$ & $155 \pm 7.07^{\mathrm{b}}$ \\
\hline Total bilirubin, $\mathrm{mg} / \mathrm{dl}$ & $0.16 \pm 0.02^{\mathrm{b}}$ & $0.15 \pm 0.02^{\mathrm{b}}$ & $0.37 \pm 0.06^{\mathrm{a}}$ & $0.31 \pm 0.06^{\mathrm{a}}$ \\
\hline Total protein, g/dl & $6.12 \pm 0.03^{\mathrm{a}}$ & $6.49 \pm 0.07^{\mathrm{a}}$ & $5.24 \pm 0.22^{\mathrm{b}}$ & $5.56 \pm 0.12^{b}$ \\
\hline Albumin, g/dl & $4.36 \pm 0.07^{\mathrm{a}}$ & $4.50 \pm 0.19^{\mathrm{a}}$ & $3.65 \pm 0.08^{b}$ & $3.93 \pm 0.13^{b}$ \\
\hline Globulin, g/dl & $1.76 \pm 0.09^{\mathrm{a}}$ & $1.99 \pm 0.26^{\mathrm{a}}$ & $1.59 \pm 0.15^{\mathrm{a}}$ & $1.63 \pm 0.08^{\mathrm{a}}$ \\
\hline Triglycerides, mg/dl & $162 \pm 2.58^{\mathrm{a}}$ & $126 \pm 1.79^{\mathrm{b}}$ & $150 \pm 6.77^{\mathrm{a}}$ & $111 \pm 6.48^{c}$ \\
\hline $\begin{array}{l}\text { Total cholesterol, } \\
\mathrm{mg} / \mathrm{dl}\end{array}$ & $79.6 \pm 1.58^{\mathrm{ab}}$ & $73.4 \pm 4.67^{\mathrm{b}}$ & $98.6 \pm 3.96^{\mathrm{ab}}$ & $104 \pm 16.0^{\mathrm{a}}$ \\
\hline Urea, mg/dl & $20.7 \pm 0.97^{\mathrm{b}}$ & $20.3 \pm 1.02^{\mathrm{b}}$ & $43 \pm 1.90^{\mathrm{a}}$ & $41.5 \pm 3.13^{\mathrm{a}}$ \\
\hline Creatinine, mg/dl & $0.77 \pm 0.06^{\mathrm{b}}$ & $0.76 \pm 0.05^{\mathrm{b}}$ & $1.35 \pm 0.09^{\mathrm{a}}$ & $1.35 \pm 0.08^{\mathrm{a}}$ \\
\hline
\end{tabular}

Values are means \pm standard errors. Means in the same row not sharing a common superscript letter are significantly different $(P<0.05)$. PCV: Packed cell volume, HB: Hemoglobin concentration, RBCs: Red blood cells count, WBCs: White blood cells count, GGT: Gamma glutamyle transferase, ALP: alkaline phosphatase, ALT: alanine aminotransferase, AST: Aspartate aminotransferase.

\section{Lipid peroxidation and antioxidant status}

OXT induced significant increase in lipid peroxidation activity in liver, kidney and testis represented by amount of MDA produced (Table 3 ). In the $\mathrm{OXT}+\mathrm{CoQ} 10$ treated rats, the level of MDA significantly reduced, however remained significantly higher than mean value recorded in control animals. MDA level in CoQ10 group did not show significant change when compared to control group. OXT induced significant decrease in the levels of both GSH and catalase as compared to control group. Concomitant administration of CoQ10 with OXT enhanced and raised the levels of those enzymes to statistically comparable values to that recorded in control group. 
Table 3: Effect of oxytetracycline (OXT) and Coenzyme Q10 (CoQ10) on lipid peroxidation (MDA) $(\mathrm{nmol} / \mathrm{g})$, reduced glutathione $(\mathrm{GSH})(\mathrm{mg} / \mathrm{g})$ and catalase $(\mathrm{mg} / \mathrm{g})$ in rats' tissues.

\begin{tabular}{cccccc}
\hline & & Control & CoQ10 & OXT & OXT+CoQ10 \\
\hline \multirow{4}{*}{ Liver } & MDA & $5.34 \pm 0.20^{\mathrm{c}}$ & $5.12 \pm 0.10^{\mathrm{c}}$ & $11.9 \pm 0.72^{\mathrm{a}}$ & $6.94 \pm 0.30^{\mathrm{b}}$ \\
& GSH & $27.8 \pm 1.20^{\mathrm{a}}$ & $30.7 \pm 1.74^{\mathrm{a}}$ & $22.8 \pm 1.68^{\mathrm{b}}$ & $31.9 \pm 1.03^{\mathrm{a}}$ \\
& Catalase & $7.83 \pm 0.32^{\mathrm{a}}$ & $7.47 \pm 0.32^{\mathrm{a}}$ & $5.33 \pm 0.27^{\mathrm{b}}$ & $7.23 \pm 0.39^{\mathrm{a}}$ \\
\hline \multirow{2}{*}{ Kidney } & MDA & $3.97 \pm 0.21^{\mathrm{c}}$ & $3.99 \pm 0.19^{\mathrm{c}}$ & $9.68 \pm 0.44^{\mathrm{a}}$ & $5.58 \pm 0.55^{\mathrm{b}}$ \\
& GSH & $17.3 \pm 1.18^{\mathrm{a}}$ & $18.4 \pm 1.72^{\mathrm{a}}$ & $10.7 \pm 0.60^{\mathrm{b}}$ & $16.3 \pm 0.86^{\mathrm{a}}$ \\
& Catalase & $7.76 \pm 0.41^{\mathrm{a}}$ & $7.65 \pm 0.24^{\mathrm{a}}$ & $3.68 \pm 0.13^{\mathrm{b}}$ & $7.43 \pm 0.17^{\mathrm{a}}$ \\
\hline \multirow{4}{*}{ Testis } & MDA & $3.42 \pm 0.18^{\mathrm{c}}$ & $3.17 \pm 0.20^{\mathrm{c}}$ & $13.4 \pm 0.32^{\mathrm{a}}$ & $7.02 \pm 0.48^{\mathrm{b}}$ \\
& GSH & $29.4 \pm 1.21^{\mathrm{a}}$ & $31.7 \pm 1.57^{\mathrm{a}}$ & $14.2 \pm 1.17^{\mathrm{b}}$ & $28.2 \pm 0.77^{\mathrm{a}}$ \\
& Catalase & $5.83 \pm 0.25^{\mathrm{a}}$ & $5.64 \pm 0.33^{\mathrm{a}}$ & $3.32 \pm 0.21^{\mathrm{b}}$ & $5.00 \pm 0.40^{\mathrm{a}}$ \\
\hline
\end{tabular}

Values are means \pm standard errors. Means with different superscripts within the same row differ significantly $(P<0.05)$.

\section{Sperm characteristics and serum testosterone levels}

As depicted in Table 4, significant decrease in both mass and individual motility was observed in OXT group compared to control group. In addition, individual progressive motility showed a significant sharp decline in OXT-treated rats compared to control group. Percentage of live sperms decreased significantly in OXT group as well. Concomitant administration of CoQ10 with OXT enhanced all forms of motility and raised percentage of live sperms in this group as compared to rats received only OXT. There was no significant change in sperm concentration among all treated groups. On the other hand, semen parameters in CoQ10 group showed statistically comparable values to that recorded in control group. OXT induced significant drop in serum testosterone levels of treated rats compared to control group. Rats received both OXT and CoQ10 showed significant increase in levels of serum testosterone when compared to OXT group, however remained significantly lower than mean value recorded in control animals (Table 4).

Table 4: Effect of oxytetracycline (OXT) and Coenzyme Q10 (CoQ10) on sperm characteristics and serum testosterone levels of male rats.

\begin{tabular}{|c|c|c|c|c|}
\hline & Control & CoQ10 & OXT & OXT + CoQ10 \\
\hline Mass motility* & $3.20 \pm 0.37^{\mathrm{a}}$ & $2.80 \pm 0.37^{\mathrm{ab}}$ & $0.60 \pm 0.40^{\mathrm{b}}$ & $2.00 \pm 0.55^{\mathrm{ab}}$ \\
\hline Total motility $\%$ & $63.0 \pm 4.36^{\mathrm{a}}$ & $63.0 \pm 5.39^{\mathrm{a}}$ & $19.0 \pm 5.34^{\circ}$ & $41.0 \pm 8.86^{\mathrm{b}}$ \\
\hline $\begin{array}{l}\text { Progressive } \\
\text { motility } \%\end{array}$ & $52.0 \pm 5.83^{\mathrm{a}}$ & $50.0 \pm 5.39^{\mathrm{a}}$ & $8.8 \pm 3.32^{\mathrm{c}}$ & $28.0 \pm 8.15^{\mathrm{b}}$ \\
\hline $\begin{array}{l}\text { Sperm concen- } \\
\text { tration }\left(10^{6} / \mathrm{ml}\right)\end{array}$ & $412 \pm 54.63^{\mathrm{a}}$ & $350 \pm 16.12^{\mathrm{a}}$ & $312 \pm 39.3^{\mathrm{a}}$ & $308 \pm 24.8^{\mathrm{a}}$ \\
\hline Alive sperm \% & $73.0 \pm 5.39^{\mathrm{a}}$ & $69.0 \pm 5.34^{\mathrm{a}}$ & $28.4 \pm 4.80^{\circ}$ & $48.0 \pm 8.60^{\mathrm{b}}$ \\
\hline $\begin{array}{l}\text { Testosterone, } \\
\mathrm{ng} / \mathrm{ml}\end{array}$ & $2.75 \pm 0.07^{\mathrm{a}}$ & $3.16 \pm 0.18^{\mathrm{a}}$ & $0.70 \pm 0.11^{\mathrm{c}}$ & $1.65 \pm 0.16^{\mathrm{b}}$ \\
\hline
\end{tabular}

Values are means \pm standard errors. Means in the same row not sharing a common superscript letter are significantly different $(P<0.05)$. *Scored at 0 to $5+$.

\section{Gross pathology}

Liver, kidneys, testis and epididymis of control and CoQ10 groups appeared grossly normal. In OXT group, there was hepatomegaly with presence of greyish white areas on the surface of the livers. Also, kidneys were markedly swollen and pale. There were no significant changes detected in testis and epididymis. Similar changes of OXT group were detected in OXT $+\mathrm{CoQ} 10$ group but were less severe.

\section{Histopathology}

Table 5 illustrates the histopathological lesions and their intensity recorded in liver, kidneys, testis and epididymis of all experimental groups comparable to control group.

Table 5: Histopathological lesions of rats' organs and lesion scoring treated with oxytetracycline (OXT) and Coenzyme Q10 (CoQ10).

\begin{tabular}{|c|c|c|c|c|}
\hline & Control & CoQ10 & OXT & OXT+CoQ10 \\
\hline \multicolumn{5}{|l|}{ Liver } \\
\hline $\begin{array}{l}\text { Hepatocytic vacuo- } \\
\text { lation }\end{array}$ & $0 \pm 0^{\mathrm{b}}$ & $0 \pm 0^{\mathrm{b}}$ & $2.83 \pm 0.17^{\mathrm{a}}$ & $1.33 \pm 0.33^{\mathrm{ab}}$ \\
\hline $\begin{array}{l}\text { Portal mononuclear } \\
\text { infiltrates }\end{array}$ & $0 \pm 0^{\mathrm{b}}$ & $0 \pm 0^{\mathrm{b}}$ & $2.83 \pm 0.17^{\mathrm{a}}$ & $2.17 \pm 0.40^{\mathrm{a}}$ \\
\hline Hepatic necrosis & $0 \pm 0^{\mathrm{b}}$ & $0 \pm 0^{\mathrm{b}}$ & $1.83 \pm 0.48^{\mathrm{a}}$ & $1.00 \pm 0.26^{\mathrm{ab}}$ \\
\hline \multicolumn{5}{|l|}{ Kidneys } \\
\hline $\begin{array}{l}\text { Vacuolated renal tubu- } \\
\text { lar epithelium }\end{array}$ & $0 \pm 0^{\mathrm{b}}$ & $0 \pm 0^{\mathrm{b}}$ & $2.50 \pm 0.22^{\mathrm{a}}$ & $1.50 \pm 0.22^{\mathrm{ab}}$ \\
\hline $\begin{array}{l}\text { Interstitial mononucle- } \\
\text { ar infiltrates }\end{array}$ & $0 \pm 0^{\mathrm{b}}$ & $0 \pm 0^{\mathrm{b}}$ & $1.67 \pm 0.21^{\mathrm{a}}$ & $1.17 \pm 0.17^{\mathrm{a}}$ \\
\hline Tubulonecrosis & $0 \pm 0^{\mathrm{b}}$ & $0 \pm 0^{\mathrm{b}}$ & $1.67 \pm 0.21^{\mathrm{a}}$ & $0.33 \pm 0.21^{\mathrm{b}}$ \\
\hline \multicolumn{5}{|l|}{ Testis } \\
\hline Testicular degeneration & $0 \pm 0^{\mathrm{b}}$ & $0 \pm 0^{\mathrm{b}}$ & $1.50 \pm 0.50^{\mathrm{a}}$ & $0.67 \pm 0.33^{\mathrm{ab}}$ \\
\hline Congestion/edema & $0 \pm 0^{\mathrm{a}}$ & $0 \pm 0^{\mathrm{a}}$ & $0.67 \pm 0.33^{\mathrm{a}}$ & $0 \pm 0^{\mathrm{a}}$ \\
\hline \multicolumn{5}{|l|}{ Epididymis } \\
\hline $\begin{array}{l}\text { Desquamated germinal } \\
\text { epithelium }\end{array}$ & $0 \pm 0^{\mathrm{a}}$ & $0 \pm 0^{\mathrm{a}}$ & $0.67 \pm 0.33^{\mathrm{a}}$ & $0 \pm 0^{\mathrm{a}}$ \\
\hline \multicolumn{5}{|c|}{$\begin{array}{l}\text { Values are means } \pm \text { standard errors. Groups in the same row not sharing a common } \\
\text { superscript letter are significantly different }(P<0.05) \text {. Lesion scoring: (0) Absent, } \\
\text { (1) Mild, (2) Moderate, (3) Severe. }\end{array}$} \\
\hline \multicolumn{5}{|l|}{ Liver } \\
\hline \multicolumn{5}{|c|}{$\begin{array}{l}\text { Control (Fig. 1A) and CoQ10 (Fig. 1B) rats showed } \\
\text { normal hepatic histoarchitecture. OXT rats exhibited diffuse } \\
\text { hepatocytic vacuolation and mononuclear cell infiltrates in portal } \\
\text { areas (Fig. 1C). Focal to multifocal hepatocytic necrosis with mono- } \\
\text { nuclears infiltration (Fig. 1D) were recorded in OXT group. Also, } \\
\text { centrilobular (Fig. 1E) and periportal hepatocytic necrosis concomi- } \\
\text { tant with inflammatory cells infiltration were noticed. OXT+CoQ10 } \\
\text { rats showed similar lesions of OXT group but were less severe in } \\
\text { intensity and pattern (Fig. 1F). Otherwise, the hepatic parenchyma } \\
\text { of OXT+CoQ10 rats appeared almost normal (Fig. 1G). }\end{array}$} \\
\hline
\end{tabular}




\section{Kidneys}

Kidneys of control (Fig. 2A) and CoQ10 (Fig. 2B) rats showed normal histologic structure. OXT treatment induced severe renal lesions such as marked vacuolation of renal tubular epithelium, perivascular lymphocytic infiltration (Fig. 2C) and detachment of renal epithelium into tubular lumina. Multifocal areas of tubulonecrosis with mononuclear cells infiltration (Fig. 2D) were noticed in renal cortex and corticomedullary junction. Some renal tubules were dilated with thinning of renal epithelium. $\mathrm{OXT}+\mathrm{CoQ} 10$ rats showed mild vacuolation of some renal tubular epithelial cells, mild perivascular lymphocytic infiltration and detachment of renal epithelium in some renal tubules (Fig. 2E). Besides, most of renal histoarchitecture were nearly normal (Fig. 2F).

\section{Testis and Epididymis}

Seminiferous tubules of control (Fig. 3A) and CoQ10 (Fig. 3B) testis were histologically normal with multiple layers of spermatogenesis. Testis of OXT group showed some degenerated buckled hyalinized seminiferous tubules (Fig. 3C) with selective destruction to primary spermatocytes. Mild interstitial congestion and edema were also noticed in OXT group. OXT+CoQ10 group (Fig. 3D) had few degenerated seminiferous tubules; however, other tubules appeared without significant histopathologic alterations (Fig. 3E). Regarding to epididymis (Fig. 4), all groups had epididymal tubules packed with sperms without significant histopathologic findings except in OXT group; there was desquamated germinal epithelium inside the lumina of caput epididymis tubules.
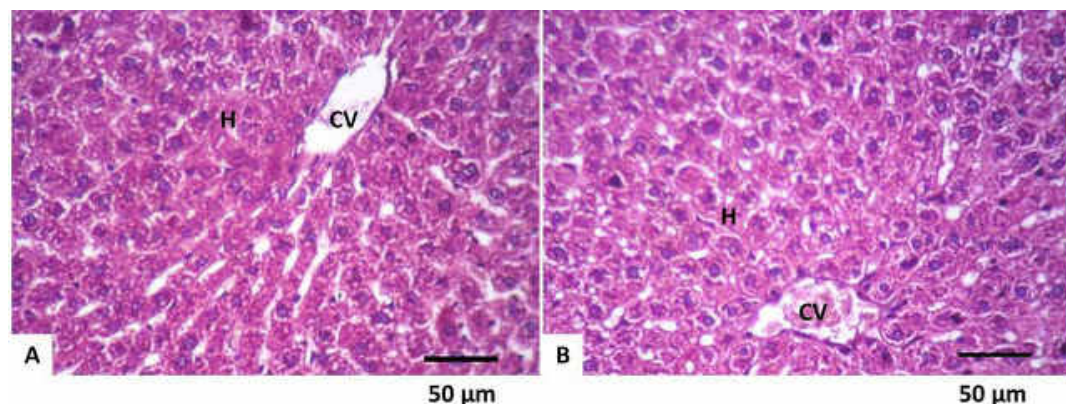

$50 \mu \mathrm{m}$

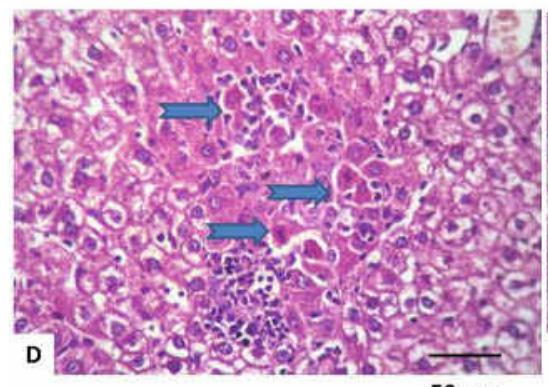

$50 \mu \mathrm{m}$

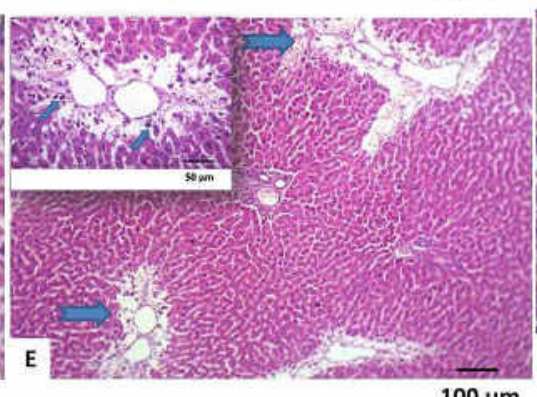

$100 \mu \mathrm{m}$

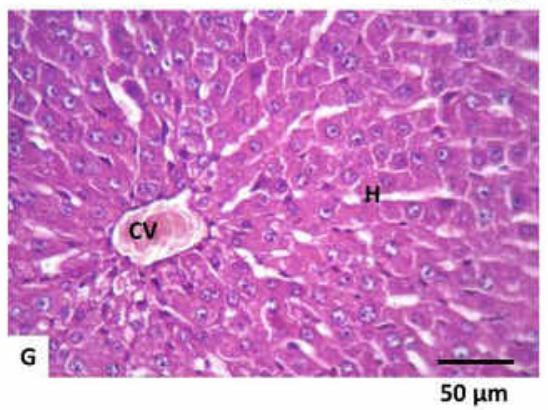

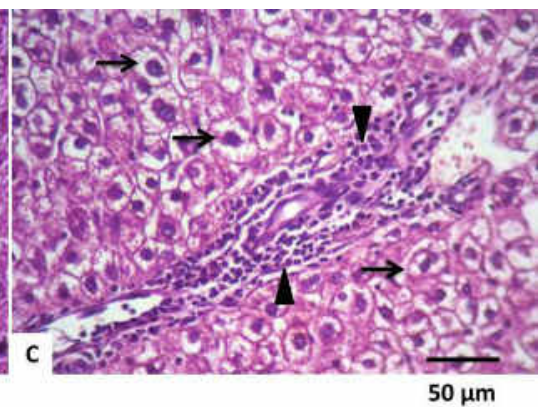

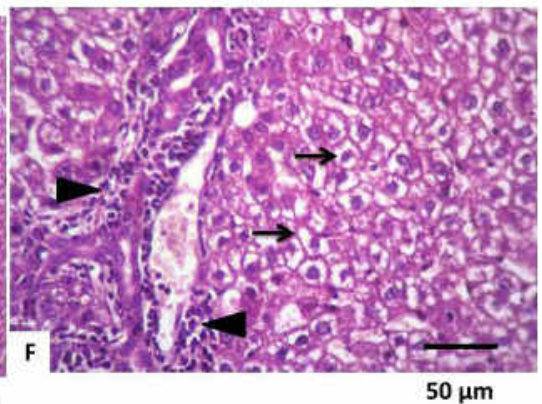

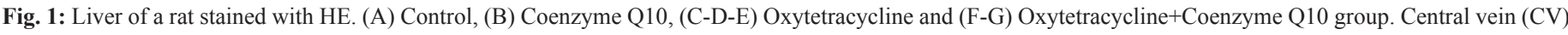

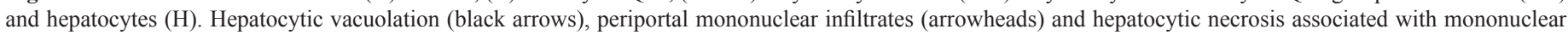
infiltrates (blue notched arrows). 

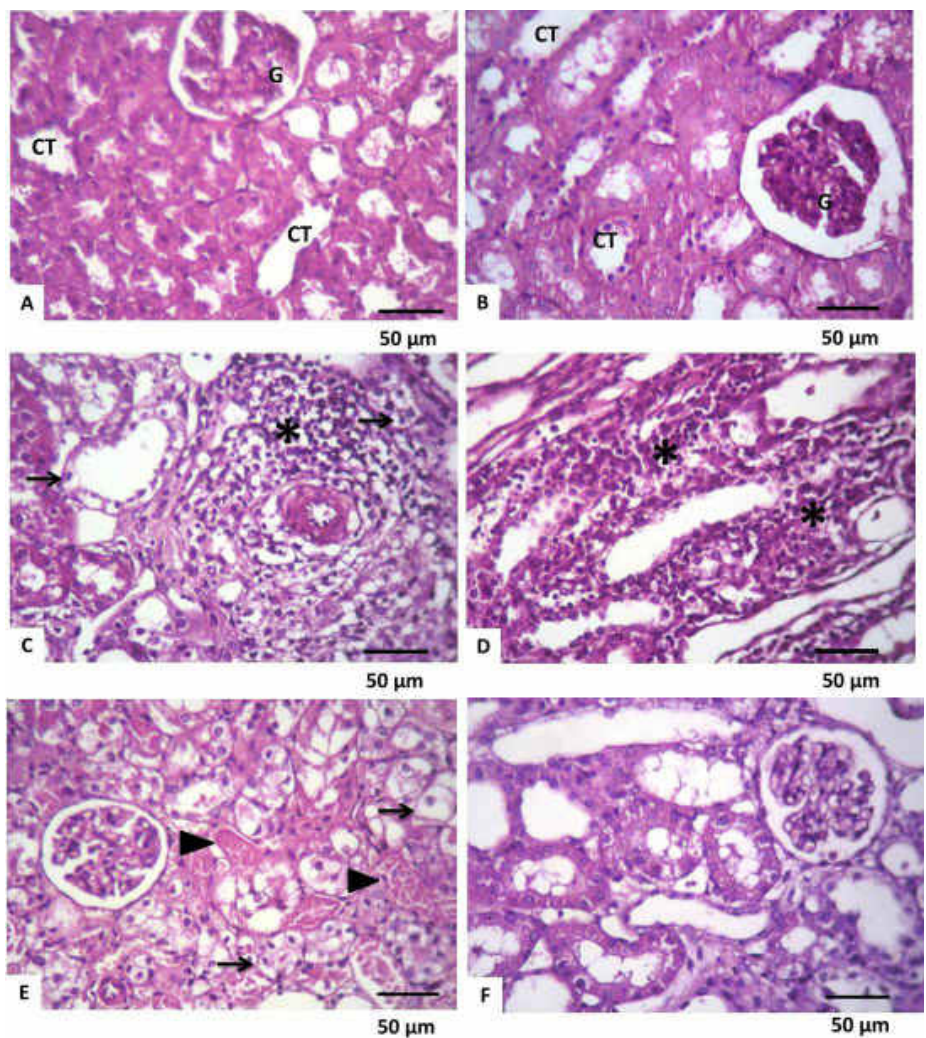

Fig. 2: Kidney of a rat stained with HE. (A) Control, (B) Coenzyme Q10, (C-D) Oxytetracycline and (E-F) Oxytetracycline+Coenzyme Q10 group. Glomerulus (G) and renal convoluted tubules (CT). Mononuclear cells infiltrate (asterisk), vacuolated renal tubular epithelium (black arrows), and detached renal epithelium (arrowheads).
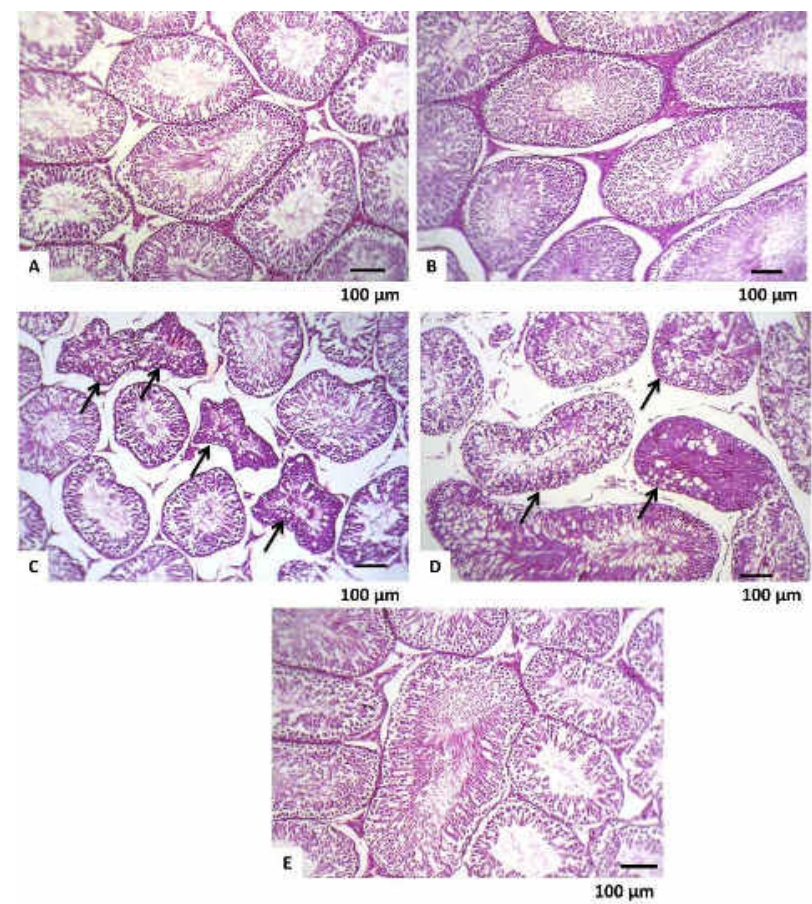

Fig. 3: Testis of a rat stained with HE. (A) Control, (B) Coenzyme Q10, (C) Oxytetracycline and (D, E) Oxytetracycline+Coenzyme Q10 group. Degenerated hyalinized seminiferous tubules (black arrows). 

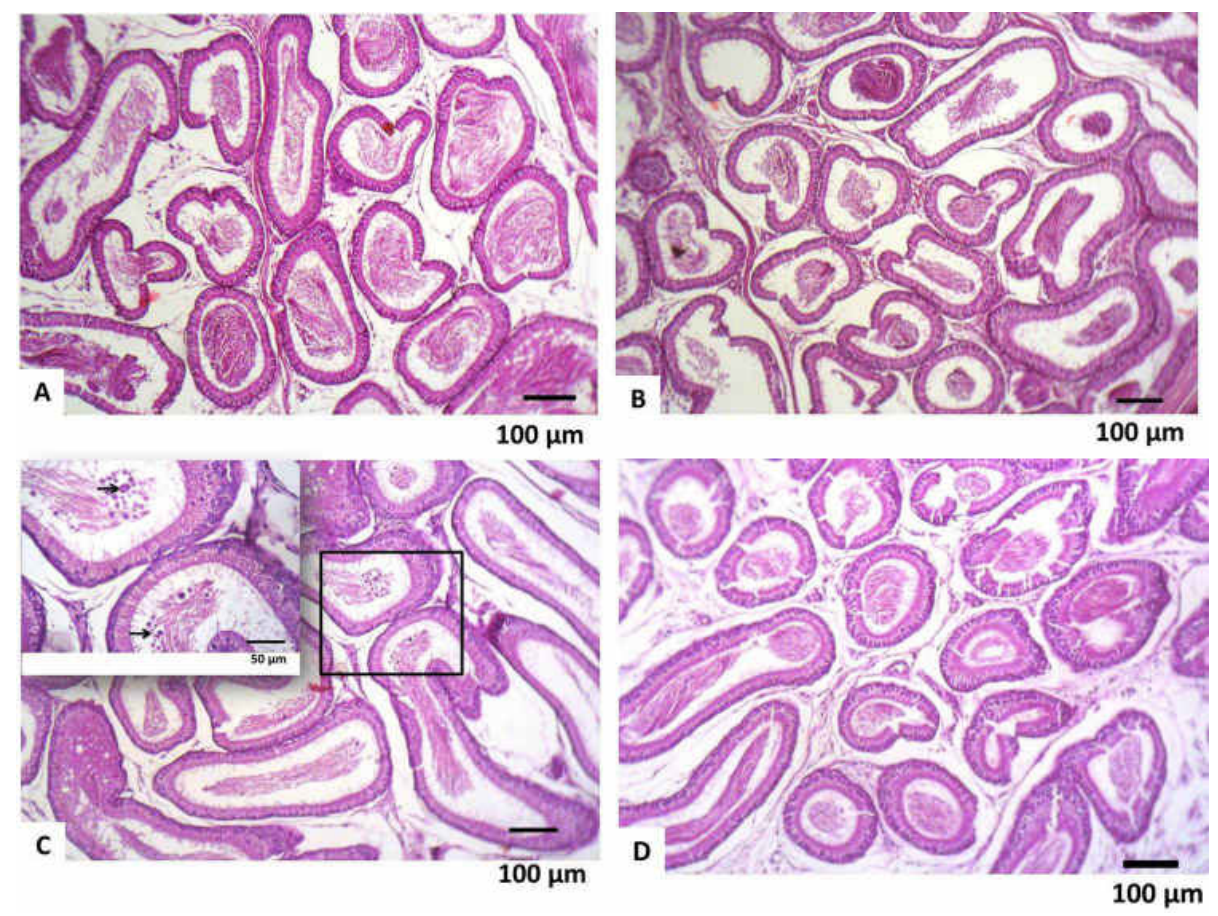

Fig. 4: Epididymis of a rat stained with HE. (A) Control, (B) Coenzyme Q10, (C) Oxytetracycline and (D) Oxytetracycline+Coenzyme Q10 group. Desquamated germinal epithelium (black arrows).

\section{DISCUSSION}

Improper use of OXT at high doses induces hepato-renal toxicity (Naseer and Alam, 1987). To our knowledge, this study is the first to document the plausible protective efficacy of CoQ10 against hepatorenal and reproductive toxicity induced by OXT in male rats. Our results indicate that OXT treatment significantly decreased body weight of rats and increased the relative liver and kidney weights. Hematological results revealed reduction in HB concentration and RBCs count in OXT treated groups. These results were parallel to those reported by Hue et al. (2015). Our study revealed that OXT induced significant leukopenia which may be due to its immunosuppressive effect. OXT immunosuppressive effect was reported in rainbow trout when administered for 14 days (Yonar, 2012) and in pigeon for 50 days (Al-Ankari, 2005). However, single dose of long acting OXT did not affect immune status of rats (Ravikumar et al., 2016). In the current study, OXT treatment increased serum GGT, ALP, AST, total bilirubin and decreased serum total protein and albumin. These results reflect the hepatic damage caused by OXT treatment. The increase in serum AST levels mirrors the injury of cell membrane and leakage of cytoplasmic enzymes to the blood (Janbaz et al., 2004). The increase in serum levels of ALP, GGT and bilirubin is due to biliary lesions (Moss and Butterworth 1974). Moreover, the reduction in serum albumin and total protein concentrations indicates failure of protein synthesis by hepatocytes (Zimmerman and Seeff et al., 1970). These functional alterations were long-established histopathologically. The hepatic structural changes prompted by OXT were diffuse hepatocytic vacuolation, mononuclear cell infiltrates in portal areas and hepatic necrosis. OXT induced hepatic damage may be due to inhibition of $\beta$ oxidation of free fatty acids and lipoprotein secretion in liver (Letteron et al.,
2003) and increased cholesterol and triglyceride biosynthesis. In our experiment, OXT did not elevate serum total cholesterol and triglycerides and no steatosis was observed in OXT treated rats. The study of Pari and Gnanasoundari (2006) is in agreement with our findings as they described the hepatic histopathological alterations induced by OXT $(200 \mathrm{mg} / \mathrm{kg} /$ day for 15 days $)$ without steatosis. Our results revealed increase in hepatic MDA and decrease in GSH and catalase enzyme in OXT treated groups. These findings were consistent with the studies of Jayanthi and Subash (2010) and Abdel-Daim and Ghazy (2015). Moreover, serum urea and creatinine values were elevated by OXT treatment indicating renal dysfunction (Gnanasoundari and Pari, 2006). Renal lesions caused by OXT were in line with previous reports of Tarara et al. (1976), Gnanasoundari and Pari (2006) and Shabana et al. (2012). CoQ10, a component of electron transport chain, has antioxidant, anti-inflammatory, and anti-apoptotic properties against acetaminophen hepatotoxicity and metabolic-stress-induced liver damage (Vasiliev et al., 2011, Fouad and Jresat, 2012). CoQ10 adjusts oxidative phosphorylation and inhibits lipid peroxidation (Bargossi et al., 1994). In our study, CoQ10 treatment in part countered lipid peroxidation (MDA) induced by OXT and enhanced GSH and catalase levels in liver and kidneys. On the basis of histopathological description and lesion scoring, CoQ10 treatment ameliorated the degenerative and necrotic lesions prompted by OXT in liver and kidneys. Our study has shown that OXT administration has deleterious effect on sperm motility/viability. Furthermore, the current work reported for the first time that OXT causes moderate damaging effect in testis via oxidative stress action as it provoked lipid peroxidation and a reduction in levels of testicular GSH and catalase. These effects were associated with significant decrease in serum testosterone level. The adverse effect of OXT on sperm motility noticed in the current work is consistent with previous 
studies reported similar observation in bucks (Onakpa et al., 2010), and rats (Oyedeji et al., 2013). In contrast to our observation, sperm viability in these studies showed no change, probably because lower doses of OXT were used (20-25mg/kg). In an in-vitro assay, minocycline at dose as low as $50 \mu \mathrm{g} / \mathrm{ml}$ was found to be toxic to bull sperm (Ahmad and Foote, 1986), likewise tetracycline was reported to cause dose-dependent irreversible decline in human sperm motility besides a decreased viability (Hargreaves et al., 1998). Impairment of sperm motility by tetracyclines family might be due to its ability to chelate calcium (Caswell and Hutchison, 1971), which is of paramount importance for sperm movement and hyperactivation necessary for fertilization (Darszon et al., 2011). The elevated levels of lipid peroxidation recorded hereby in testis of OXT-treated rats implicates that OXT might has prompted the same process in epididymal spermatozoa resulting in a decrease in their motility. Spermatozoa are highly susceptible to oxidative stress, particularly lipid peroxidation because of their great content of polyunsaturated fatty acids in plasma membrane. Oxidative stress is well recognized as a cause of male infertility due to sperm damage, deformity, and induced DNA fragmentation (Agarwal et al.,2008). Reports studied the effect of tetracyclines on histological structure of testis and epididymis are few. Histopathological examination of OXT testicular sections showed moderate degenerative changes in some seminiferous tubules, which did not affect spermatogenesis. This result explains why sperm count did not change in response to OXT treatment. These observations agree with an early study described that OXT administration for eight days in rats has negligible effects on spermatogenesis (Timmermans, 1974). The subtle changes in testis may be attributed to OXT- induced reduction in testicular GSH and catalase decreasing tissue ability to resist lipid peroxidation. An increase in relative testis weight was noted, that may due to circulatory disturbances such as congestion and edema in testis. Also, epididymal tubules of OXT group had desquamated germinal epithelium. These structural alterations may be attributed to oxidative stress and decrease in serum testosterone levels induced by OXT. Testosterone is necessary for development and function of male reproductive tissues (Mooradian et al., 1987). The observed reduction in serum testosterone concentration associated with OXT treatment is in line with a previous study that described same observation after tetracycline administration in men (Pulkkinen and Maenpaa, 1983). Contrary to this result, Hamalainen and co-workers (1987) reported that OXT has no effect on circulating testosterone level, possibly due to differences in dosage of the drug. There is no substantial evidence on mechanism of action of OXT-induced decrease in testosterone; it is speculated that disturbance in enterohepatic circulation of steroids is partially responsible for this phenomenon (Pulkkinen and Maenpaa, 1983). Whether or not OXT can directly inhibit testosterone synthesis is still questionable. In our work, supplementation of CoQ10 to OXT-treated rats resulted in relatively improved sperm motility/viability, showed androgenic action evidenced by elevated serum level of testosterone, restored relative testis weight and improved testicular and epididymal histoarcitecture. These findings are consistent with studies demonstrated that oral supplementation of CoQ10 improved sperm motility in idiopathic infertile men (Balercia et al., 2004; Balercia et al., 2009; Safarinejad 2009; 2012). Furthermore, CoQ10 as antioxidant suppressed lipid peroxidation in testis and boosted levels of testicular GSH and catalase, two naturally occurring testicular antioxidant enzymes. Similarly, oral CoQ10 induced an increase in seminal catalase and super oxide dismutase activity in infertile men (Safarinejad et al., 2012).

In conclusion, among other possible mechanisms, OXT administration induced hepatorenal and male reproductive toxicity via oxidative stress. Moreover, CoQ10 could provide partial protection against OXT-induced hepatorenal as well as reproductive dysfunction in male rats through limitation of oxidative stress triggered by OXT.

\section{CONFLICT OF INTEREST}

Authors state that there are no conflicts of interest.

\section{ACKNOWLEDGEMENTS}

We would thank Professor Dr. Mahmoud M. A. Elmaghraby for his efforts in statistical analysis.

\section{REFERENCES}

Abbitt B, Berndtson WE, Seidel GE Jr. Effect of dihydrostreptomycin or oxytetracycline on reproductive capacity of bulls. Am J Vet Res, $1984 ;$ 45:2243-2246.

Abdel-Daim MM, Ghazy EW. Effects of Nigella sativa oil and ascorbic acid against oxytetracycline-induced hepato-renal toxicity in rabbits. Iran J Basic Med Sci, 2015; 18:221-227.

Aberg F, Appelkvist EL, Dallner G, Ernster L. Distribution and redox state of ubiquinones in rat and human tissues. Arch Biochem Biophys, $1992 ; 295: 230-234$.

Aebi H. 1974. Catalase. In: H.U. Bergmeryer and H. Ulrich, "Methods of Enzymatic Analysis", $2^{\text {nd }}$ ed., Verlag Chemic, Weinhein, New York, pp. 673.

Agarwal A, Makker K, Sharma R. Clinical relevance of oxidative stress in male factor infertility: an update. Am J Reprod Immunol, 2008; 59:2-11.

Ahmad K, Foote RH. Postthaw survival and fertility of frozen bull spermatozoa treated with antibiotics and detergent. J Dairy Sci, 1986; 69:535-541

Al-Ankari AS. Immunomodulating effects of black seed and oxytetracycline in pigeons. Immunopharmacol Immunotoxicol, 2005; 27:515-520.

Alleva R, Scararmucci A, Mantero F, Bompadre S, Leoni L, Littarru GP. The protective role of ubiquinol-10 against formation of lipid hydroperoxides in human seminal fluid. Mol Aspects Med, 1997; 18:221-228.

Balercia G, Buldreghini E, Vignini A, Tiano L, Paggi F, Amoroso S, Ricciardo-Lamonica G, Boscaro M, Lenzi A, Littarru G. Coenzyme Q10 treatment in infertile men with idiopathic asthenozoospermia: a placebo-controlled, double-blind randomized trial. Fertil Steril, 2009; 91:1785-1792.

Balercia G, Mosca F, Mantero F, Boscaro M, Mancini A, Ricciardo-Lamonica G, Littarru G. Coenzyme Q (10) supplementation in infertile men with idiopathic asthenozoospermia: an open, uncontrolled pilot study. Fertil Steril, 2004; 81:93-98.

Bargossi AM, Battno M, Gaddi A, et al. Exogenous CoQ10 preserves plasma uboquinone levels in patients treated with 3-hydroxy-3-methylglutaryl coenzyme A reductase inhibitors. Int J Clin Lab Res, 1994; 24:171-176.

Caswell AH, Hutchison JD. Selectivity of cation chelation to tetracyclines: evidence for special conformation of calcium chelate. Biochem Biophys Res Commun, 1971; 43:625-630.

Coles EH. 1974. Veterinary Clinical Pathology. $1^{\text {st }}$ Ed. PP. 21213. W. B. Saunders Co. Philadelphia, London, Toronto.

Coulomb JJ, Farreau L. A new simple semi-micro method for colourimetric determination of urea. Clin Chem, 1963; 9:102.

Darszon A, Nishigaki T, Beltran C, Trevino CL. Calcium channels in the development, maturation, and function of spermatozoa. Physiol 
Rev, 2011; 91:1305-1355.

Demetrious JA. 1987. Testosterone in methods. In Clinical chemistry (Tech, A.G. and L.A. Klapalan). 2nd Ed. CVMOS Co., pp. 268. Doumas BT, Carter DD, Peters RJ, Schaffer RA. Acandidate reference method for determination of total protein in serum. 1. Development and validation. Clin Chem, 1971; 27:1642-1643.

El-Sheikh AA, Morsy MA, Mahmoud MM, Rifaai RA, Abdelrahman AM. 2012. Effect of Coenzyme-Q10 on Doxorubicin-Induced Nephrotoxicity in Rats. Adv Pharmacol Sci doi:10.1155/2012/981461.

Fassati P, Prencipe L. Serum triglycerides determined colorimetrically with an enzyme that produces hydrogen peroxide. Clin Chem, $1982 ; 28: 2077-2080$.

Fouad AA, Jresat I. Hepatoprotective effect of coenzyme Q10 in rats with acetaminophen toxicity. Environ Toxicol Pharmacol, 2012; 33:158-67.

Fromenty B, Pessayre D. Impaired mitochondrial function in microvesicular steatosis. Effects of drugs, ethanol, hormones and cytokines. J Hepatol, 1997; 26:43-53.

Gnanasoundari M, Pari L. Impact of naringenin on oxytetracycline-mediated oxidative damage in kidney of rats. Ren Fail, 2006; 28:599-605.

Hamalainen E, Korpela JT, Adlercreutz H. Effect of oxytetracycline administration on intestinal metabolism of oestrogens and on plasma sex hormones in healthy men. Gut, 1987; 28:439-445.

Hargreaves CA, Rogers S, Hills F, Rahman F, Howell RJ, Homa ST. Effects of co-trimoxazole, erythromycin, amoxycillin, tetracycline and chloroquine on sperm function in vitro. Hum Reprod, 1998; 13:1878-1886.

Helal EG, Abd El-wahab SM, Zedan GA. Effect of Curcuma longa L. on fatty liver induced by oxytetracycline in albino rats. Egyp J Hosp Med, 2011; 43:109-120.

Hue NV, Toan NV, Long LT, Fleischer G, Hong ZG. Preliminary Studies on the Toxic Effects of Degradation Products of Oxytetracycline and Chlortetracycline on Rats. J Agr Sci Tech A-B, 2015; 5:469-474.

Husdan H, Rapoport A. Estimation of the creatinine by the Jaffe reaction. A comparison of three methods. Clin Chem, 1968; 14:222.

Janbaz K, Saeed S, Gilani A. Studies on the protective effects of caffeic acid and quercetin on chemical-induced hepatotoxicity in rodents. Phytomed, 2004; 11:424-30.

Jayanthi R, Subash P. Antioxidant Effect of Caffeic Acid on Oxytetracycline Induced Lipid Peroxidation in Albino Rats. Ind J Clin Biochem, 2010; 25:371-375.

Johnson AM, Rohlfs EM, Silverman LM. 1999. Proteins. In: Burtis, CA, Ashwood, ER. editors. Tietz text book of Clinical Chemistry. 3rd Ed., Philadelphia. W.B. Saunders Company, pp. 477-540.

Kind PRN, King EG. Colourimetric determination of alkaline phosphatase. J Clin Pathol, 1954; 7:322.

Laing JA. 1979. Fertility and infertility in domestic animals. $3^{\text {rd }}$ ed. Bailliere Tindall, a division of Cassell Lt.

Letteron P, Sutton A, Mansouri A, Fromenty B, Pessayre D. Inhibition of microsomal triglyceride transfer protein: Another mechanism for drug-induced steatosis in mice. Hepatol, 2003; 38:133-140.

Mancini A, Balercia G. Coenzyme Q (10) in male infertility: physiopathology and therapy. Biofactors, 2011; 37:374-380.

Mondal M, Baruah KK, Chatterjee A, Ghosh MK. Characterization and Gene Expression Profiling of Epididymal Sperm Collected from Dead Mithun (Bos Frontalis) Bulls and its Preservation. IJBBR, 2013; 4:535-542.

Mooradian AD, Morley JE, Korenman SG. "Biological actions of androgens". Endocr Rev, 1987; 8:1-28.

Moss DW, Butterworth PJ. 1974. Enzymology and medicine. Pitman Medical, London, pp. 139.

Naseer F, Alam M. The protective effect of ascorbic acid on oxytetracycline induced nephrotoxicity and hepatotoxicity. J Pak Med
Assoc, 1987; 37:73-75.

Ohkawa HP, Ohishi W, Yagi K. Assay for lipid peroxides in animal tissues by thiobarbituric acid reaction. Anal Biochem, 1979; 95:351358.

Onakpa MM, Onifade KI, Owoleke OE. Effect of Oxytetracycline and streptomycin adminstration on fertility of the red Sokoto buck. IJARD, 2010; 1:39-45.

Oyedeji KO, Bolarinwa AF, Dare A. Effect of Tetracyclin on reproductive functions in male albino rats. IOSR-JDMS, 2013; 3:55-60.

Pari L, Gnanasoundari M. Influence of Naringenin on Oxytetracycline Mediated Oxidative Damage in Rat Liver. Basic Clin Pharmacol Toxicol, 2006; 98:456-461.

Pulkkinen MO, Maenpaa J. Decrease in serum testosterone concentration during treatment with tetracycline. Acta Endocrinol (Copenh), 1983; 103:269-272.

Ravikumar C, Jagadeesh S Sanganal, Sunilchandra U, Shridhar NB, Narayanaswamy HD, Shivashankar BP. Effect of long acting oxytetracycline formulation on immune status based on organ to body weight ratio in rats. Int J Sci Environ Technol, 2016; 5:341-347.

Reitman S, Frankel S. Colorimetric method for estimation of GOT/AST and GPT/ALT transaminases. Am J Clin Pathol, 1957; 28:56-63.

Safarinejad MR. Efficacy of coenzyme Q10 on semen parameters, sperm function and reproductive hormones in infertile men. J Urol, 2009; 182:237-248.

Safarinejad MR. The effect of coenzyme Q (10) supplementation on partner pregnancy rate in infertile men with idiopathic oligoasthenoteratozoospermia: an open-label prospective study. Int Urol Nephrol, 2012; 44:689-700.

Safarinejad MR, Safarinejad S, Shafiei N, Safarinejad S. Effects of the reduced form of coenzyme Q10 (ubiquinol) on semen parameters in men with idiopathic infertility: a double-blind, placebo controlled, randomized study. J Urol, 2012; 188:526-531.

Saraswat B, Visen PK, Patnaik GK, Dhawan BN. Protective effect of picroliv, active constituent of Picrorhiza kurrooa, against oxytetracycline induced hepatic damage. Indian J Exp Biol, 1997; 35:1302-1305.

Sedlak J, Lindsay RH. Estimation of total, protein-bound and nonprotein sulfhydryl groups in tissue with Ellman's reagent. Anal Biochem, 1968; 25:192-205.

Shabana MB, Ibrahim HM, Khadre SEM, Elemam MG. Influence of rifampicin and tetracycline administration on some biochemical and histological parameters in albino rats. JOBAZ, 2012; 65:299-308.

Sorensen AM. 1979. Breeding soundness evaluation. In: Sorensen, A.M. (ed.) Animal reproduction, principles and practices. $1^{\text {st }} \mathrm{ed}$. McGraw-Hill, New York..

Szasz G. 1974. $\gamma$ glutamyltranspeptidase. In Bergmeyer, HU, ed. methoden der enzymatistichen analyse. 3rd ed. Weinheim: verlag chemie; 757: 732 .

Tarara RP, Hansen LG, Simon J. Effects of repeated administration of oxytetracycline on kidney, liver and liver mixedfunction oxidases in the rat. Toxicol Appl Pharmacol, 1976; 35:321-331.

Timmermans L. Influence of antibiotics on spermatogenesis. J Urol, 1974; 112: 348.

Vasiliev AV, Martinova EA, Sharanova NV, Gapparov MM. Effects of coenzyme Q10 on rat liver cells under conditions of metabolic stress. Bull Exp Biol Med, 2011; 150: 416-419.

Walter M, Gerade H. Ultramicromethod for the determination of conjugated and total Bilirubin in serum or plasma. Microchemic J, 1970; 15: 231 .

Yonar ME. The effect of lycopene on oxytetracycline-induced oxidative stress and immunosuppression in rainbow trout (Oncorhynchus mykiss W). Fish Shellfish Immunol, 2012; 32:994-1001.

Zimmerman HJ, Seeff LB. 1970. Enzymes in hepatic disease. In: Diagnostic enzymology. Ed.: Goodly EE, Lea, Febiger Philadelphia pp. $24-26$. 
How to cite this article:

Oda SS, Waheeb RS, El-Maddawy ZK. Potential efficacy of Coenzyme Q10 against oxytetracycline-induced hepatorenal and reproductive toxicity in male rats. J App Pharm Sci, 2018; 8 (01): 098-107. 